\title{
Ibn-e-Sina's "Canon of Medicine"
}

\section{Syed Irfan Ahmed}

Professor and Head, Department of Medicine, Islamabad Medical \& Dental College, Islamabad Pakistan

Perhaps the most famous philosopher-scientist of a thousand years hence was Ibn-e-Sina (Avicenna) who was born near Bukhara in 980 AD. While his writings on astronomy, Islamic theology, mathematics as well as poetry gained fame, it is for his contribution in medicine that he is remembered. Al-Qanun (The Canon of Medicine), his most famous work on the subject was the standard textbook for students and practitioners alike, both in East and West and taught in medical schools of Baghdad and Europe right up to the 18 th century. ${ }^{1}$

Al-Qanun consists of five books, each subdivided into Fanns, then Fasl and finally Maqala. Book One deals with the constitution and parts of human body. Common afflictions, with their causes, complications and treatment are also described here. Materia Medica is dealt with in the Second Book. Diseases affecting a specific part of the body, or entire body as in fever, are highlighted in Books Three and Four respectively. Pharmacology, with a formulary of compound medications is outlined in Book Five. $^{1}$

In Avicenna's own words: "My plan is to deal with the general aspects of each of the two divisions of medicine, the speculative and the practical. Then I shall treat of the general principles applicable to the diagnosis of the properties of the simples, following this with a detailed account of them. Then I shall

\section{Correspondence:}

Syed Irfan Ahmed

Email: irfan.ahmad@imdcollege.com

Cite this editorial: Ahmed Sl. Ibn-e-Sina's "Canon of Medicine. J Islamabad Med Dental Coll. 2020; 9(4): 233-234 Doi: $10.35787 / j i m d c . v 9 i 4.629$ take up the disorders which befall each individual member, beginning with an account of its anatomy and that of its auxiliary. The anatomy of several members and their auxiliaries is dealt with in the first book. Having completed the account of the anatomy, I shall show the health of member is to be maintained."

"This subject being completed, I proceed to a general discourse about general diseases, their causes, the signs by which they are recognized and the modes of treatment. After this, I pass on to the special diseases and will point out in as many cases as possible. $^{2}$

I. The general diagnosis of their characters, causes and signs.

II. The special diagnostic features.

III. The general rules of treatment by

a. Singles,

b. Compounded medicines"

The section on "The Urine" is very extensive and outlines in great detail various points about its collection, characters, variations in normality, abnormalities, relationship to various disease states and methods of examination. "Points to observe in a sample of urine are quantity, odor, color, foam, texture, clarity and sediment." These points are then discussed in detail with reference to their pathological significance.

Ibn-e-Sina's description of the pulse is remarkably close to what is practiced in present times. Method of examination of the pulse at the wrist is described in great detail, with special reference to rate, rhythm, condition of the vessel walls, "emptiness" 
or "fullness" of successive beats and the pauses or intermissions, whether regular or irregular. ${ }^{2}$

According to Dr. O. Cameron Gruner, the author of "treatise on the Canon", a delightful classic, the Canon of Medicine of Avicenna has an esteemed position in modern thought. The importance of idea over material achievement is not to be forgotten.

The accomplishments of any age are subject to decay with the lapse of eras, but the ideas which give rise to them remain living through all cycles. It is agreed that there is an elevated place for Avicenna in modern thought and he shall be viewed as one, who was entrusted with a mission to express for that age, by means of various tools he found in it, an unchanging and impersonal wisdom. Today, there is the need that this wisdom should be re-expressed for this age by means of the new data, which lie in our hands. ${ }^{3}$

\section{References}

1. Habib M, Ahmed SI. Prince of Physicians. The life and times of Ibn-e-Sina (Avicenna). Islamabad, 2017.

2. Shah MH. The general principles of Avicenna's Canon of Medicine. Karachi, 1966.

3. Gruner OC. A treatise on the Canon of Medicine of Avicenna. London, 1930. Special edition, the Classics of Medicine Library, Birmingham, Alabama, 1940 